\title{
Spatio-Temporal Constraints on Moose Habitat and Carrying Capacity in Coastal Alaska: Vegetation Succession and Climate
}

\author{
Thomas R. Stephenson, ${ }^{1}$ Victor Van Ballenberghe, ${ }^{2}$ \\ James M. Peek, ${ }^{3}$ and James G. MacCracken ${ }^{4}$ \\ Authors are ${ }^{1}$ Associate Wildlife Biologist, Sierra Nevada Bighorn Sheep Recovery Program, California Department of Fish and Game, \\ 407 West Line Street, Bishop, CA 93514; ${ }^{2}$ Research Biologist (retired), US Department of Agriculture Forest Service, \\ Pacific Northwest Research Station, 3301 C Street, Suite 200, Anchorage, AK 99503-3954; ${ }^{3}$ Professor Emeritus, \\ Department of Fish and Wildlife Resources, University of Idaho, Moscow, ID 83844; and ${ }^{4}$ Wildife Biologist, \\ Timber Department, Longview Fiber Company, PO Box 667, Longview, WA 98632.
}

\begin{abstract}
We used a geographic information system and a Markov chain analysis to model vegetation succession on the Copper River Delta, Alaska, relative to moose (Alces alces) habitat availability and nutritional carrying capacity. Between 1959 and 1986 vegetation predominantly shifted from pioneer to later successional communities as a result of glacial retreat and earthquake uplift. Hypothesized vectors of vegetation composition in future decades indicate a trend toward an increase in late-successional communities. A decline in glacier-related disturbance has reduced the level of retrogression that maintains early successional communities in the outwash plain. In addition, landscape heterogeneity increased significantly between 1959 and 1986, particularly in the uplifted marsh. Winter severity was highly variable among years and was correlated with a shift in the location of moose wintering areas. As winter severity increased, there was increased use of the glacial outwash plain landform and its associated plant communities. Successional modeling suggests a decline in the availability of vegetation types important to moose during severe winters with deep snow. Low willow (Salix spp.) communities are expanding in the uplifted marsh, a landform used primarily during summer and mild winters. However, tall willow communities that provide winter forage are declining and are being replaced by Sitka spruce (Picea sitchensis [Bong] Carr) forest in the glacial outwash plain. Consequently, nutritional carrying capacity of moose on the outwash plain during winter will decline by $42 \%$ during 1959-2013.
\end{abstract}

\section{Resumen}

Usamos un sistema de información geográfica y el análisis de la cadena de Markov para modelar la sucesión de la vegetación del "Copper River Delta," Alaska, en relación con la disponibilidad de hábitat y capacidad de carga nutricional para el alce (Alces alces). Entre 1959 y 1986 la vegetación fue predominantemente cambiada de comunidades pioneras a comunidades de mayor desarrollo en la sucesión, esto, como resultado de la contracción del glaciares y elevaciones por terremotos. Los vectores hipotéticos de la composición de la vegetación en décadas futuras indican una tendencia hacia un incremento de las comunidades de las etapas finales de la sucesión. Una disminución del disturbio relacionado con el glacial ha reducido el nivel de retrogresión que mantiene las comunidades iniciales de la sucesión en las planicies de material sedimentario. Además, la heterogeneidad del paisaje se incrementó significativamente entre 1959 y 1986, particularmente en las áreas pantanosas emergidas. La severidad del invierno es altamente variable entre años y estuvo correlacionada con el cambio en la localización de las áreas invernales del alce. Conforme la severidad del invierno incrementó, hubo un aumento en el uso de las planicies sedimentarias del glacial y sus comunidades vegetales asociadas. El modelo sucesional sugiere una reducción en la disponibilidad de tipos de vegetación importantes para el alce durante los inviernos severos con nieve profunda. Las comunidades de "Low willow"(Salix spp.) se están expandiendo hacia las áreas húmedas emergidas, una topoforma usada principalmente durante el verano e inviernos moderados. Sin embargo, en las planicies sedimentarias del glacial, las comunidades de "Tall willow," que proveen forraje en invierno, están disminuyendo y siendo remplazadas por bosques de "Sitka spruce" (Picea sitchensis [Bong] Carr). Consecuentemente, durante el invierno la capacidad de carga nutricional para le alce de las planicies de sedimentarias disminuirá en $42 \%$ durante 1959-2013.

Key Words: Alces alces, habitat selection, landscape heterogeneity, Markov chain, winter severity

Financial and logistical support was provided by the US Dept of Agriculture Forest Service, Pacific Northwest Research Station, Anchorage, Alaska; US Dept of Agriculture Forest Service, Cordova Ranger District, Cordova, Alaska; US Dept of Agriculture Forest Service, Copper River Delta Institute, Cordova, Alaska; the University of Idaho, Dept of Fish and Wildlife Resources, Moscow, Idaho; and the Grants-in-Aid program, National Rifle Association, Washington, DC.

At the time of the research, the senior author was Graduate Research Assistant, Dept of Fish and Wildlife Resources, University of Idaho, Moscow, ID 83844.

Correspondence: Thomas R. Stephenson, Sierra Nevada Bighorn Sheep Recovery Program, California Dept of Fish and Game, 407 West Line St, Bishop, CA 93514 . Email: tstephenson@dfg.ca.gov

Manuscript received 1 May 2004; manuscript accepted 18 January 2006. 


\section{INTRODUCTION}

Moose in coastal Alaska inhabit a temporally dynamic environment that is characterized by extreme variability at all time scales (Haukioja and Lehtila 1992). Among seasons, winter and summer forage quantity and quality differ by orders of magnitude and consequently winter habitat availability ultimately limits moose abundance (Stephenson 1995; MacCracken et al. 1997). Over years, quality of summer forages vary with respect to the intensity of solar radiation (Bo and Hjeljord 1991) and winter forage abundance varies with the extent and duration of snowfall (Coady 1974). Finally, through decades and centuries, the extents of habitats favorable to moose are determined by vegetation succession in glacial and fire-dominated landscapes of Alaska (LeResche et al. 1974; Wolff and Zasada 1979). The extreme short-term temporal variability in moose landscapes exacerbates the importance of spatial heterogeneity in the distribution of habitat types. Because of their high requirement for forage biomass, early stages of plant succession are important to moose (Oldemeyer and Regelin 1987; Regelin et al. 1987; Saether and Anderson 1990). Willow communities are especially important in coastal floodplain areas such as the Copper River Delta, Alaska (MacCracken and Van Ballenberghe 1993; Stephenson 1995; MacCracken et al. 1997). A disturbance regime that ensures the persistence of shrub communities distributed in a diverse mosaic is essential for maintaining high moose densities.

The ultimate availability of habitats selected by moose on the Copper River Delta depends on vegetation succession that both creates and eliminates habitats that support moose. In addition to the small-scale $(<1 \mathrm{ha}$ ) autogenic successional processes of facilitation, tolerance, and inhibition (Connell and Slatyer 1977; Burrows 1990), the allogenic events of glacial retreat (Viereck 1966; Reiners et al. 1971; Walker et al. 1986; Chapin et al. 1994), flooding, and earthquake uplift (Thilenius 1990a, 1990b) alter the rate of succession on large spatial scales. Winter availability of forage biomass as it relates to moose carrying capacity on a landscape is further dictated by the heterogeneity in vegetation communities during winter. This heterogeneity exists spatially not only because of underlying patterns of vegetation but also as a result of snow deposition that varies according to topography and microclimate. Habitat availability, and hence the forage resource, on wintering areas is further modified by variation in snowfall within and among years (Coady 1974; Miquelle et al. 1992). A spatially dynamic mosaic of vegetation communities provides a diversity of habitats that fulfill the seasonal requirements of forage quality and availability.

Although successional changes often have been discussed in the context of habitat quality, rarely have these changes been quantified and incorporated into predictions of change in habitat availability and carrying capacity at the landscape level. We evaluated long-term habitat availability determined by patterns of vegetation change relative to the nutritional ecology of moose on the Copper River Delta using a geographic information system (GIS). Furthermore, we assessed habitat selection and movements relative to winter severity. We hypothesized that there were significant changes in the composition of moose habitat on the Copper River Delta following earthquake uplift in 1964 and glacial retreat during the last 2 decades. We further quantified moose habitat carrying capacity in the context of successional change and winter severity.

\section{MATERIALS AND METHODS}

MacCracken (1992) described the climate, geology, and geography of the Copper River Delta in detail. The scope of our analysis was defined by the primary winter range identified by MacCracken et al. (1997) and extended north and south to include a cross-section of the delta (representing $\sim 20 \%$ of the entire Copper River Delta) to evaluate the dominant successional mechanisms affecting moose habitat. Although boundaries of the mapping project were restricted primarily to the interannual winter range of the Copper River Delta moose population and by physical features such as mountains, glaciers, and open water, estimates of moose habitat use were based on data from the entire Copper River Delta. Porter and Church (1987) warned against spurious results obtained when a priori study area boundaries are used. Glaciated mountains $(1000-2000 \mathrm{~m})$ and associated mature temperate rainforest define the perimeter of the delta and glacial floodplains that we mapped. Elevations ranged from 0 to $130 \mathrm{~m}$. Mean annual precipitation was $231 \mathrm{~cm}$ and mean annual snowfall was $310 \mathrm{~cm}$. Mean monthly temperatures ranged from $-6 \mathrm{C}$ in January to $12 \mathrm{C}$ in July. Moose are not endemic to the Copper River Delta, having been excluded by the local topography (i.e., the Chugach Mountains and its associated glaciers), but were introduced during 1949-1958. Recent glacial retreat along the Copper River may now permit natural immigration to the Copper River Delta from interior Alaska.

The study area was subdivided into glacial outwash plain and uplifted marsh (Fig. 1). Although Boggs (1994) identified glacial moraine as an additional landform within the study area, we included this within the outwash plain landform because of its limited area and similarity to outwash plain, relative to the processes of primary succession. Furthermore, the Copper River Highway (Fig. 1) was selected as the boundary between outwash plain and uplifted marsh, even though small inclusions of outwash plain extend south of the highway. The highway also functions as a dike, altering the flow of water and nutrients on the study area.

\section{Vegetation Change}

Vegetation/land cover maps were created from 1:15 840 nominal-scale aerial photographs. Black-and-white and colorinfrared photography were used to create the 1959 and 1986 coverages, respectively. Interpretation of stereo pairs was conducted using a mirror stereoscope. Polygons of homogeneous areas of vegetation and land cover $>400 \mathrm{~m}^{2}$ were delineated and assigned to 1 of 23 categories (Table 1) based on the classification system developed by Viereck et al. (1992). Photo interpretation accuracy of the 1986 photography was ensured by ground truthing and sampling of vegetation plots throughout the project area during a related experiment (Stephenson et al. 1998b). Validation of the 1959 photography interpretation used 1966 1:7,000 true-color photography (transects flown at $6.6-\mathrm{km}$ intervals) for low elevation, 


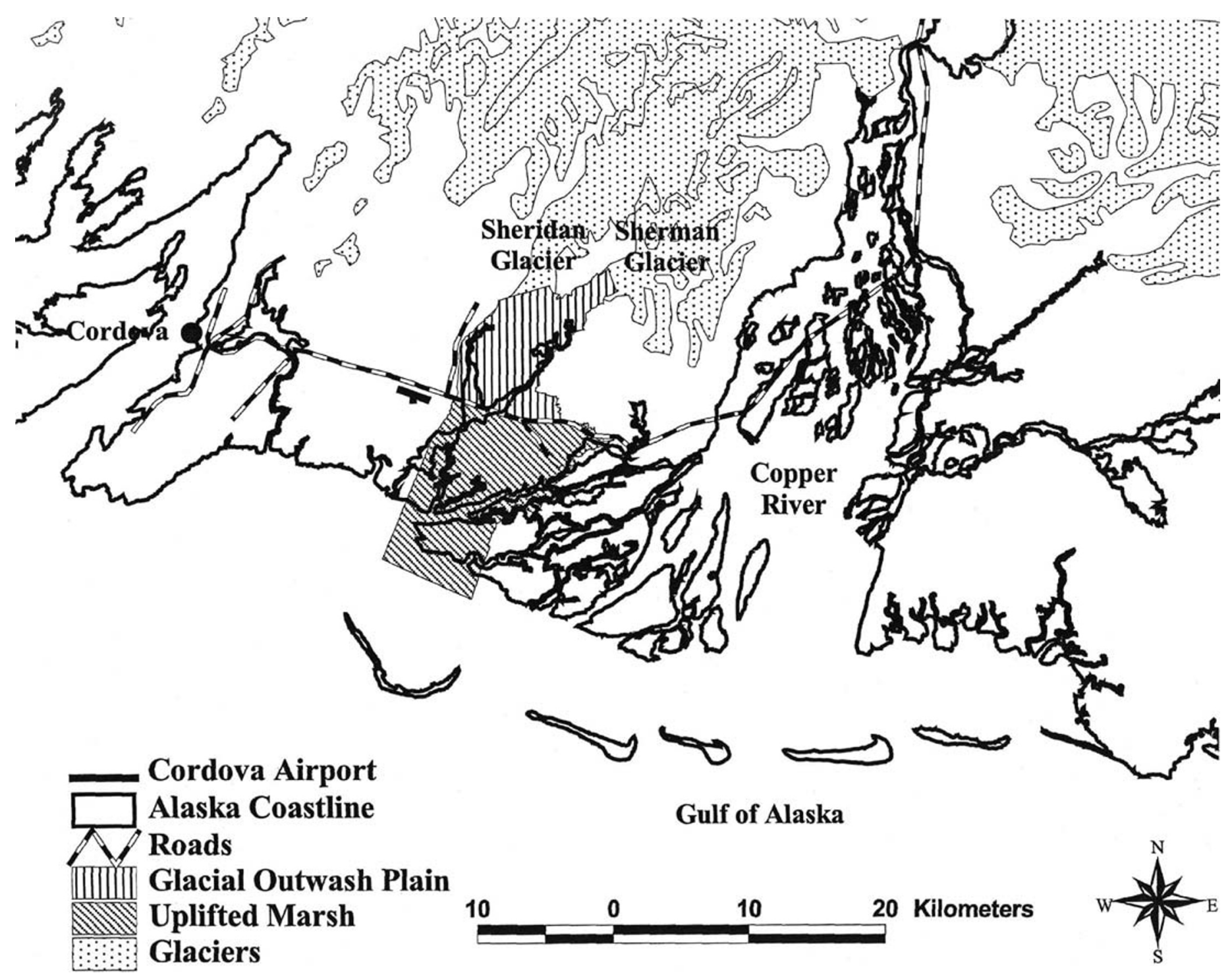

Figure 1. Map of the Copper River Delta, Alaska, and vicinity. The location of the highway, airport, and areas of glacial outwash plain and uplifted marsh, where land cover was mapped in detail, are identified.

immediate postearthquake identification of vegetation and land cover. In addition, Crow (1968) described broad vegetation patterns on the Copper River Delta at the time of the earthquake, which aided in photo interpretation. Potyondy et al. (1975) noted that detailed identification of aquatic types was not possible using the 1959 photography, so these types were classified as pond.

Program MDSD (Carto Instruments, Inc., Corvallis, OR) enabled digitizing directly from individual aerial photographs (Warner and Carson 1991). Map coverages for 1959 and 1986 were generated in a GIS (ARC/INFO, Environmental Systems Research Institute, Inc., Redlands, CA) from the digitized photos, and polygons were assigned a cover type. We created 1959 and 1986 coverages with identical boundaries before analysis (Figs. 2 and 3). To analyze vector data, we determined the total area and percent change of each vegetation/land cover type within each coverage. In addition to documenting changes in the area of each cover type, habitat diversity and landscape structure also were evaluated to assess changes in landscape pattern. The following indices were calculated in INFO: mean perimeter:area ratio, which indicates the relative amount of edge; mean fractal dimension $=\log$ area/ $\log ($ perimeter $/ 4)$ which approaches a value of 2 as patch size and boundary complexity increases (Krummel et al. 1987); and shape index = - $(0.282 \times$ perimeter $) /(\text { area })^{0.5}$, which compares the shape of a patch to that of a circle of equal area (shape index $=1$ ) (Patton 1975). Total area and percent change of land cover type also were computed for the glacial outwash plain and the uplifted marsh.

Vector data were converted to a raster format for analysis of vegetation change and predictive successional modeling. We overlaid the 1959 and 1986 coverages and generated cell counts in the form of a transition matrix that represented the probability of changing from one cover type to another from 1959 to 1986. To facilitate analysis and interpretation of the modeling, the original 23 cover types were condensed to 9 (Table 1). Cover types were condensed based on their relative importance to moose (see MacCracken et al. 1997), their similarity (Viereck et al. 1992), or their limited occurrence. 
Table 1. Original vegetation/land cover types used in change detection analysis on the Copper River Delta, Alaska, and cover types condensed for modeling of glacial outwash plain analysis.

\begin{tabular}{|c|c|c|c|c|c|}
\hline Condensed cover type & Abbreviation & Original cover type & Abbreviation & Canopy closure and landform & Common species composition \\
\hline Gravel & GRAV & Gravel & GRAV & Floodplain or moraine & - \\
\hline \multirow[t]{3}{*}{ Low sweetgale-willow } & SWWI & Low sweetgale & SWGA & (Canopy $50 \%-100 \%$ ) & Myrica gale L./graminoid \\
\hline & & Low willow-graminoid & WIGR & (Canopy 10\%-50\%) & Graminoid/M. gale/Salix spp. L. \\
\hline & & Low willow-sweetgale & WISW & (Canopy 50\%-100\%) & Salix spp./M. gale/Graminoid \\
\hline Tall open alder-willow & TOAW & Tall open alder-willow & TOAW & Open tall (canopy 25\%-75\%) & Alnus crispa (Alt.) Pursh/Salix spp. \\
\hline Tall closed alder-willow & TCAW & Tall closed alder-willow & TCAW & Closed tall (canopy $75 \%-100 \%$ ) & A. crispa/Salix spp. \\
\hline \multirow[t]{2}{*}{ Cottonwood } & COTT & Woodland cottonwood & WOCO & $\begin{array}{l}\text { Deciduous woodland } \\
\text { (canopy } 10 \%-25 \%)\end{array}$ & $\begin{array}{l}\text { Populus trichocarpa Torr. \& } \\
\text { Gray ex Hook./A. crispa/Salix spp }\end{array}$ \\
\hline & & Open cottonwood & OPCO & $\begin{array}{l}\text { Open decidious (canopy } \\
25 \%-75 \% \text { ) }\end{array}$ & $\begin{array}{l}\text { Populus trichocarpa/A. crispal } \\
\text { Salix spp. }\end{array}$ \\
\hline \multirow[t]{2}{*}{ Mixed spruce-cottonwood } & MSC & $\begin{array}{l}\text { Woodland mixed } \\
\text { spruce-cottonwood }\end{array}$ & WMSC & $\begin{array}{l}\text { Mixed woodland (canopy } \\
10 \%-25 \% \text { ) }\end{array}$ & $\begin{array}{l}\text { Picea sitchensis/Populus } \\
\text { trichocarpa/A. crispa/Salix spp. }\end{array}$ \\
\hline & & $\begin{array}{l}\text { Open mixed } \\
\text { spruce-cottonwood }\end{array}$ & OMSC & Open mixed (canopy 25\%-75\%) & $\begin{array}{l}\text { Picea sitchensis/Populus } \\
\text { trichocarpa/A. crispa/Salix spp. }\end{array}$ \\
\hline Woodland spruce & WOSP & Woodland spruce & WOSP & $\begin{array}{l}\text { Coniferous woodland } \\
\text { (canopy } 10 \%-25 \%)\end{array}$ & $\begin{array}{l}\text { Picea sitchensis/A. crispa/Salix } \\
\text { spp./M. gale }\end{array}$ \\
\hline \multirow[t]{2}{*}{ Spruce } & SPRU & Open spruce & OPSP & $\begin{array}{l}\text { Open coniferous } \\
\text { (canopy } 25 \%-75 \% \text { ) }\end{array}$ & $\begin{array}{l}\text { Picea sitchensis/A. crispal } \\
\text { Salix spp. }\end{array}$ \\
\hline & & Closed spruce & CLSP & $\begin{array}{l}\text { Closed coniferous } \\
\qquad \text { (canopy } 75 \%-100 \%)\end{array}$ & $\begin{array}{l}\text { Picea sitchensis/ } \\
\text { Vaccinium spp. L. }\end{array}$ \\
\hline \multirow[t]{10}{*}{ Other } & OTHR & Glacier & GLAC & - & - \\
\hline & & Glacial lake & GLLK & - & - \\
\hline & & Pond & POND & - & may include aquatic vegetation \\
\hline & & River or Slough & RVSL & Glacial river or tidal slough & - \\
\hline & & Rock & ROCK & - & - \\
\hline & & Mud & MUD & Seasonal or tidal flooding & - \\
\hline & & Mud/sedge & MUSE & Mesic (canopy < 50\%) & Carex spp. L. \\
\hline & & Emergent aquatics & EMER & Wet (emergent) & $\begin{array}{l}\text { Carex spp./Menyanthes } \\
\quad \text { trifoliate L./Equisetum spp. L. }\end{array}$ \\
\hline & & Graminoid & GRAM & Mesic & $\begin{array}{l}\text { Carex spp./Calamagrostis spp. } \\
\text { Adans./Deschampsia spp. Beauv. }\end{array}$ \\
\hline & & Bog & BOG & Mosses (bog) & Bryophyte/Carex spp. \\
\hline
\end{tabular}

Each principal diagonal element of the transition matrix was a retention probability, representing the proportion of the study area remaining in or returning to its original cover type during the 27-year period. The off-diagonal elements were transition probabilities, indicating the rate at which cover types change to other types during the interval. Matrix elements above the diagonal represented succession, a change toward older plant communities. Elements below the diagonal indicated retrogression to pioneering communities as a result of disturbance such as flooding. Because of the more linear, predictable nature of succession on glacial outwash plain (Viereck 1966), relative to earthquake-uplifted marsh, predictive modeling was restricted to the area north of the highway (Fig. 1).

A Markov chain model (Van Hulst 1979; Usher 1981; Jenkins and Wright 1987) programmed in SAS (SAS Inc., Cary, NC) was used to make predictions about vegetation change in the glacial outwash plain. An iterative model was used to project the composition of the outwash plain over multiple 27-year periods using the formula:

$$
P_{t+1}=P_{t} T
$$

where T equals the transition matrix and $P_{t}$ equals the vector of present cover type proportions. The model was projected forward in time until community composition became approximately stable.

\section{Winter Severity and Moose Habitat Use}

Daily snow depth measurements were obtained from Federal Aviation Administration (National Oceanic and Atmospheric Administration 1993) observations at the Cordova/Mudhole Smith Airport (Fig. 1), situated immediately west of the primary moose winter range. Parker et al. (1984) determined that energy expenditure for movement increased exponentially in ungulates as snow depth exceeded carpus (front knee) height. Therefore, winter severity was defined using the number of days when snow depth exceeded the knee height of a yearling cow moose, $53 \mathrm{~cm}$ (T. R. Stephenson, unpublished data, 1992) at the airport. We defined winter severity as follows: very severe ( $>90$ days with snow depth exceeding $53 \mathrm{~cm}$ ), severe (61-90 days), moderate (31-60 days), mild (1-30 days), and very mild (0 days).

Snow depths at the airport were measured on level pavement and were less than that in the field. To compare field snow 
depths with airport estimates, we measured snow depths at permanent sampling sites every 3 to 4 weeks during winter. Ten random depth measurements were obtained at each site. We then calculated a ratio for each site that represents the difference between the mean field measurement and the airport measurement. MacCracken et al. (1997) defined primary and secondary moose winter ranges on the Copper River Delta. Primary winter range was the area immediately adjacent to the Cordova airport that exhibited minimum snow depth during winter. Secondary winter range included the area on the perimeter of the primary range that exhibited greater snow depths because of proximity to glaciers, higher elevation, or the colder microclimate associated with the Copper River Canyon. Mean field:airport snow depth ratio was calculated for each vegetation type from 2 to 12 sites within the primary and secondary ranges.

Twenty-eight female moose were immobilized and marked with frequency-specific, color-coded radio collars $(150 \mathrm{MHz})$ to enable individual identification and delineation of large-scale population-level movements. Radio-collared moose were located primarily using fixed-wing aircraft every 3 to 14 days. Aerial locations were supplemented with ground locations obtained during direct observation of feeding sites. All telemetry locations (1 802) were plotted on US Geological Survey 1:25 000 or 1:63 360 topographic maps and recorded using Universal Transverse Mercator grid coordinates to the nearest $100 \mathrm{~m}$. Visual observations were made for $>95 \%$ of winter locations. To maintain quasi-independence of observations (Swihart and Slade 1985), locations were evenly distributed throughout the monitoring period and among animals.

MacCracken et al. (1997) defined winter as 1 November through 30 April based on shrub phenology and snowfall. Winter range delineation was determined annually by pooling radio-locations of individual females within years. Program DC80 (Cary 1985) was used to calculate a core $(50 \%)$ harmonic mean use area (Dixon and Chapman 1980). This approach identified the area most intensively used during each winter but excluded outlying locations generally associated with migration between the winter and summer ranges. A harmonic mean center of activity also was calculated for each core use area to quantify locational shifts among years. Second-order habitat use (Johnson 1980) was assessed by intersecting annual core use areas with the 1986 vegetation coverage to determine the proportion of each cover type available within home ranges among different winters.

MacCracken et al. (1997) evaluated home ranges and second- and third-order habitat selection by individual male and female moose on the Copper River Delta; there was no evidence of sexual segregation at a landscape scale on the winter range. Because we were interested in use of habitats at the population level relative to winter severity, all locations within years were combined to determine a core use area. This core use area was then used to identify resource use by the population within the study area. Because $10 \%-20 \%$ of the population of adult cow moose was collared within any given year, the analysis should represent the population.

\section{Carrying Capacity of Moose}

Historic, present, and future nutritional carrying capacity of moose on the western portion of the Copper River Delta was modeled using a modification of the approach used by MacCracken et al. (1997) that compared range supply and animal demand on the Delta. We used estimates of forage abundance, generated by applying species-specific biomass regressions to stem diameters in permanent plots, in the outwash plain during winter (MacCracken et al. 1997; Stephenson et al. 1998b). We also used estimates of daily forage intake and sex ratio for the study area formulated by MacCracken et al. (1997). The extent of each habitat type used in our model to calculate the future forage base was based on estimates projected in our Markov chain analysis. Another notable difference from the approach of McCracken et al. (1997) included reducing available forage biomass by adjusting for browse burial under snow as estimated by Stephenson et al. (1998b), whereby permanent sites with flagging on shrubs in 5 height classes were used to measure burial by snow repeatedly during winter. In addition, we limited the useable biomass of less-preferred forages (i.e., nonwillow species) based on actual diet composition (Stephenson 1995; MacCracken et al. 1997); hence, we assumed that diet mixing (Miquelle and Jordan 1979; Hobbs and Spowart 1984) must occur to ensure adequate nutrient concentrations in the diet (Hobbs and Swift 1985) and that intake of less-preferred species is limited by the ability of animals to detoxify secondary compounds (Bryant et al. 1991). Biomass of nonwillow shrubs were considered available only up to the proportion (e.g., alder [3\%], sweetgale [7\%], cottonwood $[1 \%]$ ) at which they could continue to be mixed in the diet with available willows.

We calculated nutritional carrying capacity during the same periods used in the Markov chain analysis. During each period, we estimated the number of animals that the outwash plain could support during winter under 2 conditions: one where no browse was buried under snow and a more severe scenario where browse burial varied by vegetation community but averaged $40 \%-50 \%$ in the tall willow (e.g., alder-willow and cottonwood-willow types) and $80 \%-90 \%$ in the low willow habitats (e.g., sweetgale-willow and willow-graminoid types).

\section{Statistical Analyses}

Differences in vegetation composition between 1959 and 1986 were tested using contingency table analysis. Student's $t$ test was used to compare indices of landscape structure between 1959 and 1986 and a Bonferroni correction $(P<0.05)$ was applied to multiple pairwise comparisons. Differences in winter severity among 1987-1993 were analyzed using $\chi^{2}$ goodnessof-fit. The relationship between winter severity and the core area harmonic center was examined using Spearman rank correlation analysis. Contingency table analysis was used to test for differences in moose habitat use among years. Spearman rank correlation analysis was used to test the relationship between winter severity and habitat use.

\section{RESULTS}

\section{Vegetation Change}

Vegetation composition on the Copper River Delta changed between 1959 and $1986\left(\chi^{2}=2954\right.$, df $\left.=22, P<0.001\right)$, characterized by a shift from pioneer to later successional 


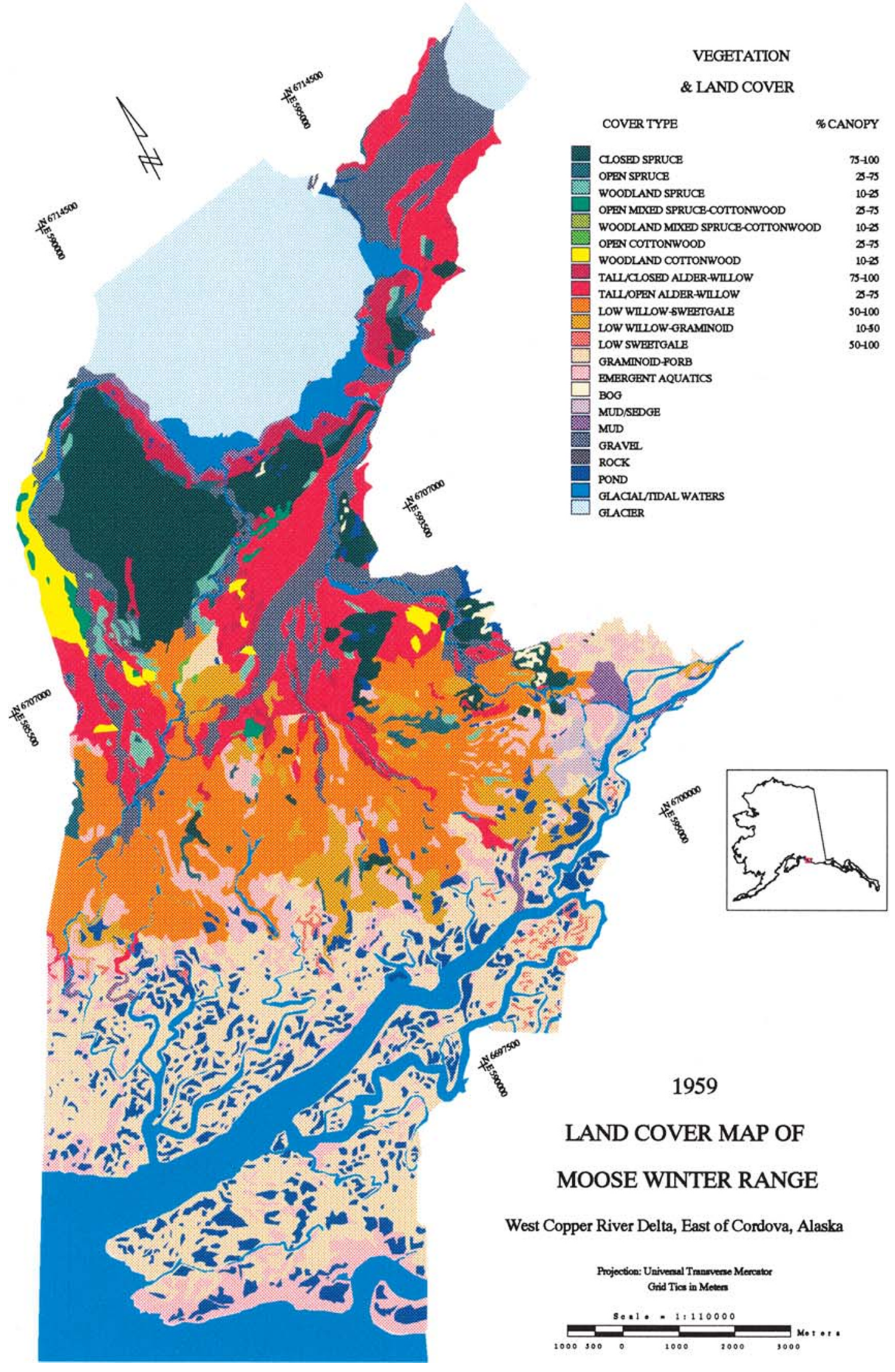

Figure 2. Vegetation and land cover of the moose winter range on the Copper River Delta, Alaska, in 1959. 


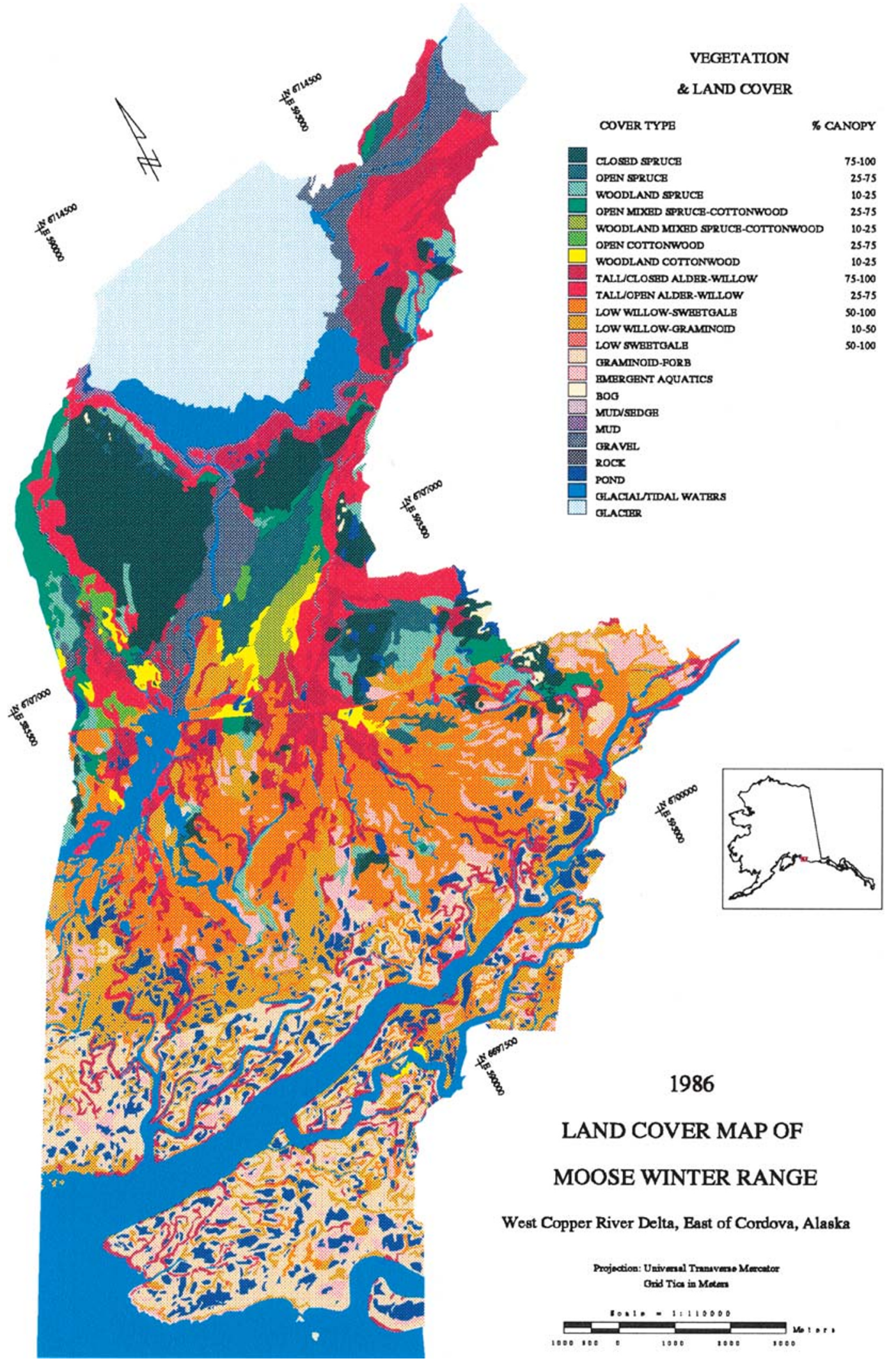

Figure 3. Vegetation and land cover of the moose winter range on the Copper River Delta, Alaska, in 1986. 
Table 2. Total area (ha) and assessment of change by vegetation/land cover type on the Copper River Delta moose winter range study area; subdivided into glacial outwash plain and uplifted marsh.

\begin{tabular}{|c|c|c|c|c|c|c|c|c|}
\hline \multirow[b]{3}{*}{ Type $^{1}$} & \multicolumn{4}{|c|}{ Outwash plain } & \multicolumn{4}{|c|}{ Uplifted marsh } \\
\hline & \multicolumn{2}{|c|}{ Total area } & \multicolumn{2}{|c|}{ Change } & \multicolumn{2}{|c|}{ Total area } & \multicolumn{2}{|c|}{ Change } \\
\hline & 1959 & 1986 & ha & 1986:1959 & 1959 & 1986 & ha & 1986:1959 \\
\hline GLAC & 1835.0 & 1519.7 & -315.4 & $0.8^{2}$ & 0 & 0 & 0 & - \\
\hline GLLK & 201.4 & 301.9 & 100.5 & 1.5 & 0 & 0 & 0 & - \\
\hline POND & 47.6 & 69.4 & 21.8 & 1.4 & 839.9 & 814.2 & -25.7 & $1.0^{2}$ \\
\hline RVSL & 83.2 & 100.5 & 17.3 & 1.2 & 3232.2 & 3381.6 & 149.3 & 1.0 \\
\hline ROCK & 2.5 & 2.7 & 0.2 & 1.1 & 0.1 & 0 & -0.1 & - \\
\hline GRAV & 1172.4 & 564.7 & -607.8 & 0.5 & 121.7 & 1.3 & -120.4 & 0.01 \\
\hline MUD & 61.9 & 76.5 & 14.6 & 1.2 & 82.6 & 0.5 & -82.1 & 0.01 \\
\hline MUSE & 0 & 0 & 0 & 0 & 84.7 & 1.8 & -83.0 & 0.02 \\
\hline EMER & 4.7 & 8.8 & 4.1 & 1.9 & 1173.4 & 569.3 & -604.1 & 0.5 \\
\hline GRAM & 34.3 & 0 & -34.3 & & 3000.6 & 1755.0 & -1245.6 & 0.6 \\
\hline WIGR & 73.4 & 96.6 & 23.2 & 1.3 & 448.2 & 1434.9 & 986.6 & 3.2 \\
\hline SWGA & 0 & 0 & 0 & 0 & 50.4 & 0 & -50.4 & - \\
\hline WISW & 156.4 & 77.1 & -79.3 & 0.5 & 1782.6 & 2043.7 & 261.1 & 1.1 \\
\hline TOAW & 1033.4 & 760.5 & -272.9 & 0.7 & 220.7 & 115.8 & -104.9 & 0.5 \\
\hline TCAW & 294.6 & 669.9 & 375.3 & 2.3 & 34.7 & 800.7 & 766.1 & 23.1 \\
\hline WOCO & 168.1 & 97.5 & -70.6 & 0.6 & 1.2 & 28.1 & 26.9 & 23.4 \\
\hline OРCO & 5.2 & 54.4 & 49.3 & 10.5 & 0.7 & 0.03 & -0.7 & 0.04 \\
\hline WMSC & 0 & 105.1 & 105.1 & & 0 & 0 & 0 & 0 \\
\hline OMSC & 45.6 & 275.9 & 230.2 & 6.1 & 9.5 & 46.9 & 37.4 & 4.9 \\
\hline WOSP & 84.8 & 255.9 & 171.1 & 3.0 & 41.6 & 132.1 & 90.5 & 3.2 \\
\hline OPSP & 61.2 & 389.6 & 328.4 & 6.4 & 88.7 & 58.8 & -29.9 & -34 \\
\hline CLSP & 1154.4 & 1094.6 & -59.8 & 0.9 & 82.3 & 111.6 & 29.3 & 1.4 \\
\hline $\mathrm{BOG}$ & 12.7 & 11.6 & -1.1 & 0.9 & 10.8 & 10.6 & -0.1 & 1.0 \\
\hline Total & 6532.9 & 6532.9 & - & - & 11307.0 & 11307.0 & - & - \\
\hline
\end{tabular}

${ }^{1}$ Types are defined in Table 1.

${ }^{2}$ Ratio of cover type area in 1986 to 1959 (an index of change).

communities. Division of the study area into glacial outwash plain and uplifted marsh landforms (Boggs 1994) facilitates discussion relative to the successional processes operating in each subarea.

Of mechanistic importance in the outwash plain is the $17 \%$ decline in toe size of Sheridan Glacier and a $50 \%$ increase in the lake at the foot of the glacier (Table 2; Figs. 2 and 3). The May and July dates for the 1959 and 1986 aerial photographs, respectively, confound comparison of the area in active river channels on the Copper River Delta because of the increase in glacial meltwater during summer. For example, the 21\%

Table 3. Indices of landscape structure and heterogeneity calculated for the Copper River Delta moose winter range.

\begin{tabular}{lcc}
\hline Index & 1959 & 1986 \\
\hline Polygon number & 1360 & 2261 \\
Polygon perimeter sum (km) & 2560.1 & 3744.4 \\
Mean perimeter:area ratio (SD) & $0.060(0.091) \mathrm{a}^{1}$ & $0.076(0.138) \mathrm{b}$ \\
Mean fractal dimension (SD) & $1.885(0.116) \mathrm{a}$ & $1.854(0.130) \mathrm{b}$ \\
Mean shape index (SD) & $1.689(0.937) \mathrm{a}$ & $1.884(1.125) \mathrm{b}$ \\
\hline
\end{tabular}

${ }^{1}$ Means between years within the same row that share the same letter are not significantly different $(P<0.05)$ according to Student's $t$ test. Bonferroni correction $(P<0.05)$ applied to multiple pairwise comparisons. increase in river-slough area did not correspond to the reduction from 3 to 1 river channels that exit Sheridan Lake (Figs. 2 and 3). Correspondingly, there were declines in gravel $(52 \%)$, willow-sweetgale (51\%), open alder-willow $(26 \%)$, and woodland cottonwood $(42 \%)$ communities. In contrast, later successional communities, representing $25 \%$ of the outwash plain, increased and included alder-willow $(2.3 \times)$, open cottonwood $(10.5 \times)$, open spruce-cottonwood $(6.1 \times)$, woodland spruce $(3.0 \times)$, and open spruce $(6.4 \times)$.

South of the Copper River Highway in the uplifted marsh, pond area remained relatively stable (Table 2). However, herbaceous communities such as emergent aquatics and graminoid-forb declined by $51 \%$ and $42 \%$, respectively. The woody plant communities of willow-graminoid $(3.2 \times)$, willow-sweetgale $(1.1 \times)$, closed alder-willow $(23.1 \times)$, woodland cottonwood $(23.4 \times)$, open spruce-cottonwood $(4.9 \times)$, woodland spruce $(3.2 \times)$, and closed spruce $(1.4 \times)$ increased.

Indices of landscape structure (Table 3 ) indicated a significant $(P<0.05)$ increase in the amount of edge and a decrease in patch size between 1959 and 1986. Perimeter:area ratio and shape index tend to increase as area of a patch decreases relative to edge. In contrast, fractal dimension decreases as the area of a patch decreases. Landscape heterogeneity increased, particularly in the uplifted marsh as a result of shrub inva- 
Table 4. Transition probabilities among condensed cover types used in Markov chain model of glacial outwash plain on the Copper River Delta, Alaska.

\begin{tabular}{llllllllll}
\hline & \multicolumn{10}{c}{ 1986 Cover types } \\
\cline { 2 - 10 } 1959 & GRAV & SWWI & TOAW & TCAW & COTT & MSC & WOSP & SPRU & OTHR \\
\hline GRAV & 0.206 & 0.005 & 0.345 & 0.151 & 0.041 & 0.145 & 0.034 & 0.027 & 0.045 \\
SWWI & 0.187 & 0.447 & 0.057 & 0.093 & 0.015 & 0.002 & 0.075 & 0.030 & 0.095 \\
TOAW & 0.035 & 0.032 & 0.167 & 0.237 & 0.050 & 0.082 & 0.100 & 0.258 & 0.038 \\
TCAW & 0.033 & 0.005 & 0.096 & 0.417 & 0.064 & 0.036 & 0.066 & 0.211 & 0.072 \\
COTT & 0.043 & 0.007 & 0.018 & 0.018 & 0.075 & 0.462 & 0.202 & 0.169 & 0.006 \\
MSC & 0.119 & 0.000 & 0.000 & 0.014 & 0.007 & 0.411 & 0.038 & 0.411 & 0.000 \\
WOSP & 0.264 & 0.071 & 0.039 & 0.078 & 0.170 & 0.016 & 0.030 & 0.300 & 0.032 \\
SPRU & 0.054 & 0.001 & 0.030 & 0.014 & 0.002 & 0.007 & 0.021 & 0.849 & 0.023 \\
OTHR & 0.059 & 0.010 & 0.044 & 0.034 & 0.000 & 0.003 & 0.004 & 0.005 & 0.842 \\
\hline
\end{tabular}

${ }^{1}$ Types are defined in Table 1.

sion along slough levees, which dissected the landscape further (Figs. 2 and 3).

We projected vegetation change only for the outwash plain north of the Copper River Highway. Transition probabilities among the cover types indicated that the majority of shifts between 1959 and 1986 were to later successional communities (Table 4; probabilities above the diagonal). All community types except spruce (open and closed) and the "other" category exhibited retention probabilities of less than $50 \%$. Cover types exhibiting the greatest persistence included glacier, glacial lake, pond, river-slough, willow-sweetgale, closed spruce, and bog and are largely included in the "other" category in Table 4. Change to spruce-cottonwood and spruce (open and closed) types exhibited the highest succession probabilities.

Between 1959 and 1986, proportions of gravel and open alder-willow declined and the later transitional types of closed alder-willow, spruce-cottonwood, woodland spruce, and spruce (open and closed) increased (Table 5). The hypothesized vectors for the years 2013 and 2040 indicated a continuation of the trend toward an increase in later successional communities. By the year 2202, a stable composition for the outwash plain was predicted with each transitional type composing less than $9 \%$ of the area and spruce (open and closed) and the "other" category composing $45 \%$ and $20 \%$, respectively.

Table 5. The proportion of Copper River Delta glacial outwash plain occupied by various cover types during 1959, 1986, and 3 hypothesized vectors $(2013,2040,2202$ [stable]) generated using a Markov chain model.

\begin{tabular}{llllll}
\hline Type $^{1}$ & 1959 & 1986 & 2013 & 2040 & 2202 \\
\hline GRAV & 0.180 & 0.086 & 0.079 & 0.078 & 0.076 \\
SWWI & 0.035 & 0.027 & 0.023 & 0.020 & 0.014 \\
TOAW & 0.158 & 0.116 & 0.083 & 0.076 & 0.070 \\
TCAW & 0.045 & 0.103 & 0.104 & 0.095 & 0.080 \\
COTT & 0.027 & 0.023 & 0.026 & 0.024 & 0.021 \\
MSC & 0.007 & 0.058 & 0.064 & 0.064 & 0.057 \\
WOSP & 0.013 & 0.039 & 0.038 & 0.036 & 0.034 \\
SPRU & 0.186 & 0.227 & 0.289 & 0.335 & 0.451 \\
OTHR & 0.349 & 0.320 & 0.294 & 0.272 & 0.197 \\
\hline
\end{tabular}

${ }^{1}$ Types are defined in Table 1.

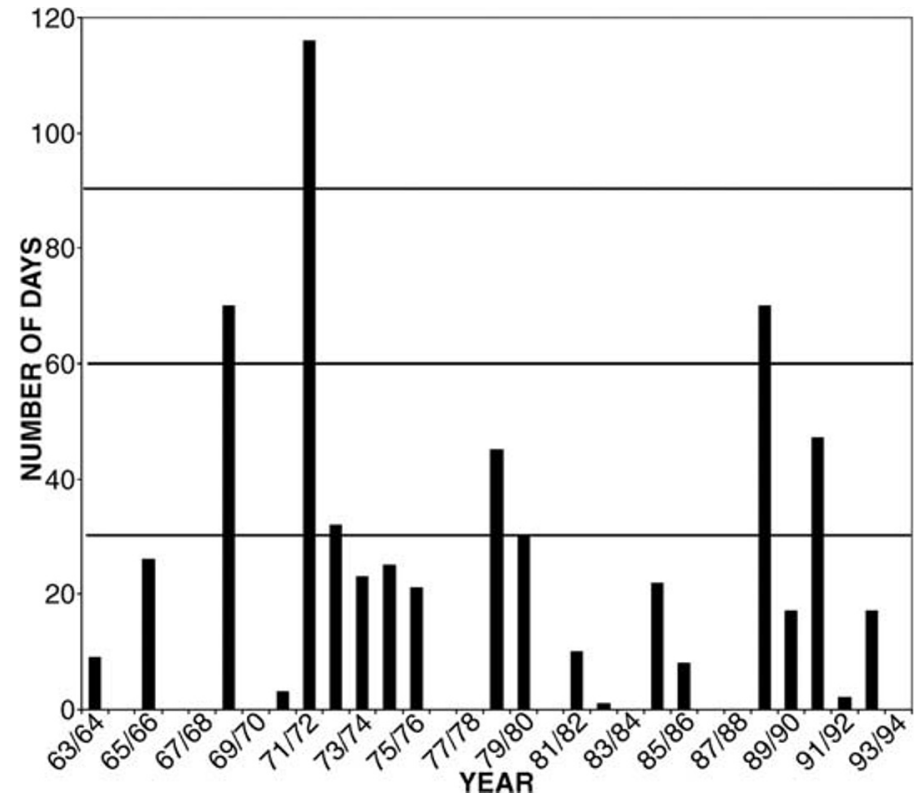

Figure 4. Number of days with snow depth $>53 \mathrm{~cm}$ at the Cordova/ Mudhole Smith airport (immediately west of the primary moose winter range) on the Copper River Delta, Alaska, during 1963-1994. Winter severity was defined as follows: very severe ( $>90$ days with snow depth exceeding $53 \mathrm{~cm}$ ), severe (61-90 days), moderate (31-60 days), mild (1-30 days), and very mild ( 0 days).

\section{Winter Severity and Moose Habitat Use}

Snow depths on the Copper River Delta varied greatly during 1987-1993. Values for winter severity varied between 0 and 70 during 1987-1993. Winter severity differed from the expected mean of 27 during 1987-1993 $\left(\chi^{2}=131.24, \mathrm{df}=4, P<0.001\right)$. During 1963-1994, very mild, mild, moderate, severe, and very severe winters occurred during 11, 14, 3, 2, and 1 years, respectively (Fig. 4). Vegetation types in primary winter range important to moose exhibited field:airport snow depth ratios between 0.94 and 4.20 (Table 6). In contrast, ratios in secondary range varied from 3.26 to 8.20 . Although open alderwillow snow depths were slightly greater in the primary winter range during 1990-1991, in general snow depths were less and snow persisted for shorter periods in open alder-willow than other denser shrub communities.

Winter severity was significantly correlated with a shift in the location of wintering areas. There was a significant northerly $(r=1.0, P<0.001)$ and westerly $(r=-0.9, P=0.03)$

Table 6. Mean ratio of field to Cordova/Mudhole Smith airport snow depth measurements by vegetation type within the primary and secondary moose winter range areas on the Copper River Delta, Alaska.

\begin{tabular}{|c|c|c|c|c|c|c|}
\hline \multirow{2}{*}{$\begin{array}{l}\text { Plant } \\
\text { community }{ }^{1}\end{array}$} & \multicolumn{2}{|c|}{ 1990-1991 } & \multicolumn{2}{|c|}{ 1991-1992 } & \multicolumn{2}{|c|}{ 1992-1993 } \\
\hline & Primary & Secondary & Primary & Secondary & Primary & Secondary \\
\hline TCAW & 0.9 & 3.5 & 2.7 & 8.2 & 4.2 & 4.3 \\
\hline TOAW & 1.2 & 5.9 & 1.7 & 4.9 & 1.9 & 3.3 \\
\hline WISW & - & - & - & - & 1.1 & - \\
\hline WOSP & - & - & 2.9 & - & 4.2 & - \\
\hline
\end{tabular}

${ }^{1}$ Types are defined in Table 1. 
Table 7. Proportional availability of habitats within moose winter range core areas on the Copper River Delta, Alaska, by year and winter severity.

\begin{tabular}{lccccc}
\hline Type $^{1}$ & $1987-1988$ & $1988-1989$ & $1990-1991$ & $1991-1992$ & $1992-1993$ \\
Winter severity & Very mild & Severe & Moderate & Very mild & Mild \\
\hline POND & 0.0481 & 0.0273 & 0.0208 & 0.0201 & 0.0239 \\
RVSL & 0.0324 & 0.0159 & 0.0122 & 0.0206 & 0.0158 \\
GRAV & 0.0007 & 0.0155 & 0.0021 & 0.0012 & 0.0041 \\
MUD & 0.0001 & 0 & 0 & 0 & 0 \\
EMER & 0.0842 & 0.0548 & 0.0127 & 0.0599 & 0.0504 \\
GRAM & 0.043 & 0.0066 & 0 & 0.0001 & 0.0027 \\
WIGR & 0.0922 & 0.0603 & 0.0576 & 0.0521 & 0.0492 \\
WISW & 0.454 & 0.3433 & 0.2764 & 0.4895 & 0.3873 \\
TOAW & 0.0256 & 0.0695 & 0.1002 & 0.0392 & 0.0573 \\
TCAW & 0.1318 & 0.1253 & 0.2713 & 0.1667 & 0.1413 \\
WOCO & 0.0072 & 0.0263 & 0.0528 & 0.011 & 0.0278 \\
OPCO & 0 & 0.0031 & 0 & 0 & 0 \\
WMSC & 0.0001 & 0.0331 & 0.0414 & 0.0031 & 0.0385 \\
OMSC & 0.0043 & 0.0149 & 0.0022 & 0.0004 & 0.0081 \\
WOSP & 0.0296 & 0.0546 & 0.0304 & 0.0457 & 0.0618 \\
OPSP & 0.0206 & 0.087 & 0.0599 & 0.0448 & 0.0733 \\
CLSP & 0.0253 & 0.0571 & 0.0599 & 0.0457 & 0.0586 \\
BOG & 0.0007 & 0.0052 & 0 & 0 & 0 \\
\hline TSPE & & & & &
\end{tabular}

${ }^{1}$ Types are defined in Table 1.

shift in the core area with increasing winter severity. A shift of $>2 \mathrm{~km}$ in the moose core use area activity center occurred between very mild and severe winters and represents movement by wintering moose into the outwash plain from the uplifted marsh as snow depth increased. Availability of habitat within core wintering areas of moose (Table 7) differed among years $\left(\chi^{2}=1297, \mathrm{df}=68, P<0.001\right)$. As winter severity increased, moose increased use of the glacial outwash plain landform and its associated plant communities of gravel ( $r=0.90, P=0.04)$, open alder-willow $(r=0.90, P=0.04)$, and open spruce $(r=0.90, P=0.04)$. Furthermore, as winter severity increased, access to the willow-sweetgale community by moose declined $(r=-0.80, P=0.10)$.

\section{Moose Carrying Capacity}

Estimates of the nutritional carrying capacity of moose in the outwash plain declined by 32\% during 1959-2202 from 1110 to 762 animals, if no browse burial under snow occurs (Table $8)$. Under severe snow conditions during the same interval, however, a $54 \%$ decline in carrying capacity occurred with the outwash plain only supporting 261 animals in the year 2013 . For estimates that incorporate browse burial under snow, $80 \%$ of the decline in carrying capacity occurs by year 2013 .

\section{DISCUSSION}

\section{Vegetation Change}

The long term allogenic mechanisms of earthquake uplift and glacial retreat are the dominant forces of vegetation succession on the Copper River Delta that primarily affect the uplifted marsh and outwash plain, respectively. To some degree,
Table 8. Estimates of the nutritional carrying capacity for moose in the glacial outwash plain winter range of the west Copper River Delta, Alaska, during 1959-2202 under very mild (no snow) and severe winter conditions.

\begin{tabular}{lrrrrr}
\hline Browse burial by snow & 1959 & 1986 & 2013 & 2040 & 2202 \\
\hline None & 1110 & 1126 & 950 & 871 & 762 \\
Severe $(\sim 50 \%)$ & 453 & 310 & 261 & 239 & 211 \\
\hline
\end{tabular}

tectonic uplift and subsidence affect the entire delta and operate over centuries. Glacial outwash dynamics operate at smaller scales and tend to affect portions of the delta. Boggs (1994) suggested that 2 temporal scales are relevant to the allogenic processes on outwash plains: yearly fluvial cycles of flow, deposition, and erosion, and long-term glacial advance and retreat.

Subtle changes in small-scale glacial dynamics have manifested themselves through effects on vegetation succession and moose winter range availability at a larger scale. Sheridan Glacier receded from the terminal moraine, resulting in the formation of 1 large glacial lake from the original 3 lakes (Figs. 2 and 3) and by 1986 only 1 outlet through the moraine and 1 river existed. Consequently, the proportion of early transitional cover types such as gravel and open alder-willow declined substantially in the outwash plain during 1959-1986 because of the decrease in area disturbed by glacial rivers. Midtransitional communities such as closed alder-willow and spruce-cottonwood existed in greater proportions in 1986 than in 1959.

Walker et al. (1986) and Chapin et al. (1994) discussed the importance of initial establishment by mid-and late-successional (i.e., as defined by their persistence into climax communities) species (Salix spp., Alnus spp., Populus spp., and Picea spp.) on disturbed sites because their invasion may be inhibited, rather than facilitated, by the dense presence of initial colonizers. Chapin et al. (1994) noted that the alder stage provides a net facilitative effect for spruce and cottonwood seedlings that establish prior to development of a dense alder stand. Successional changes at Glacier Bay, Alaska, (a region with similar climate and species composition to the Copper River Delta) were explained by life history traits, competitive inhibition, and facilitation (Chapin et al. 1994). Similarly on the Copper River Delta, processes of facilitation and inhibition may only affect the rate of succession. In contrast to glacial retreat and tectonic activity, these processes operate at the scale of individual plants but affect equally large landscapes.

Vegetation change in the outwash plain on the Copper River Delta was characterized by 2 factors: 1) increasing establishment of spruce from adjacent mature spruce stands facilitated by high seed rain, and 2) herbivory by snowshoe hares (Lepus americanus) on willow (Bryant 1985) and moose on willow and cottonwood (MacCracken et al. 1997) that reduced the abundance of these species in plant communities, hastening successional advance. Moose carrying capacity during severe winters may be closely related to the abundance of preferred tall browse species such as cottonwood and Sitka willow, which remain available above deep snow. Furthermore, removal of willow and cottonwood through browsing may decrease competitive inhibition in stands with developing spruce (Chapin et al. 1994). 
The predictable, linear nature of primary succession on glacial outwash plains (Viereck 1966; Walker et al. 1986) and deglaciated sites (Reiners et al. 1971; Chapin et al. 1994) facilitated modeling future conditions of this landform on the Copper River Delta. In contrast, the rate of succession on Copper River Delta earthquake uplifted marsh is less predictable (Thilenius 1990a). Usher (1981) cautioned against using Markovian models where transition probabilities did not remain constant in time. Potentially, a period of rapid succession occurred following the uplift but the rate may decline again if the maturing vegetation reaches a new moisture threshold. Extensive shrub succession occurred on the southern Copper River Delta by 1986 (Figs. 2 and 3).

Thilenius (1990b) noted that Alaskan coastal wetlands exhibit a natural progression from herbaceous to woody vegetation and that this succession was occurring pre-earthquake on the Copper River Delta but at a slower rate. He suggested that tectonic uplift has altered the rate but not the trajectory of vegetation succession on the uplifted marsh. Following uplift, the proximate mechanism for change was the elimination of tidal inundation. Boggs (2000) recognized distinct successional sequences on the uplifted marsh for levees and pond basins. On levees, a sequence from graminoid to alder-willow to cottonwood-spruce occurs, whereas in pond basins, peat deposition and water depths dictate succession along a gradient from aquatic, to emergent, to mesic herbaceous, to shrub-dominated wetland, to a dwarf tree (fen or bog) community (Boggs 2000). Boggs (2000) suggested that the uplifted marsh will eventually become an extensive bog-fen complex; ponds will fill with peat and encroach upon shrub and tree levee communities, converting them to peat land as well. Hence, bogs are the climax vegetation on the Copper River Delta, barring additional disturbance.

\section{Winter Severity and Moose Habitat Use}

Winter severity varied greatly among years on the Copper River Delta and snow depths varied considerably among vegetation types and sites. Moose responded to deep snow by concentrating in outwash plain community types within the primary winter range. Typically, this meant migrating farther $(>2 \mathrm{~km})$ from early winter transitional ranges in outlying areas of the uplifted marsh. During periods with less snow, moose occupied areas with a higher proportion of willow-sweetgale and closed alderwillow. However, as snow depth increased, moose increased use of relatively open canopy cottonwood and spruce types. Moose select more mature spruce and deciduous habitats during deep snow (Peek et al. 1976; Hundertmark et al. 1990; Ballard et al. 1991; Miquelle et al. 1992; MacCracken et al. 1997).

Compared to recorded maximum snow depths and the duration of deep snow on the Copper River Delta, the conditions observed during this study were not extremely severe. However, the response of moose to deeper snow illustrates behavior that occurs in response to more severe conditions. Sandegren et al. (1985) observed that adult moose initiated fall migration at an average snow depth of $42 \mathrm{~cm}$. During a severe winter such as 1971-1972 when snow depths on the Copper River Delta in March reached $251 \mathrm{~cm}$, moose may be particularly dependent on the outwash plain habitats. In less than 50 years this introduced moose population has developed a migratory routine for avoiding deep snow and locating available browse. Reynolds (1976) identified primary moose winter range during 1974-1976 as similar to current use.

Annually, moose select habitat based on available forage, particularly woody browse. Miquelle et al. (1992) observed a positive correlation between forage biomass and habitat use during all seasons for all sex-age classes of moose except females with calves during summer and females during a severe winter. MacCracken (1992) and Stephenson (1995) determined that Barclay and Sitka willow composed from $60 \%-90 \%$ of moose diets on the Copper River Delta annually. We observed a decline in open alder-willow, a principal foraging habitat in the outwash plain, but there was a concurrent increase in the closed alder-willow, open cottonwood, woodland sprucecottonwood, open spruce-cottonwood, and open spruce communities. Browse density is less in the later successional communities, but the browse is more available during deep snow when these habitats are the most important. In contrast, much of the winter range in the uplifted marsh is low willowsweetgale and is buried during deep snow winters (MacCracken 1992). Morrison (2001) emphasized the need for habitat studies to identify limiting factors (e.g., winter forage availability) and focus on underlying currencies such as nutrition.

The decline in early successional communities such as gravel and open alder-willow and the increase in more mature types foretells a future decline in the forage base in the outwash plain. Our model predicts that, between 1986 and 2013, the proportion of successional stages of closed alder-willow, cottonwood, spruce-cottonwood, and woodland spruce will remain relatively stable, while the earlier stages will continue to decline (Table 5). By 2040, closed alder-willow also will begin to decline and subsequently the cottonwood communities follow. Wolff and Zasada (1979) determined that willow communities on the Tanana River floodplain provided the most browse during 10 to 16 years postdisturbance. By 28 years postdisturbance available forage had declined by an order of magnitude and after 80 years forage had declined to almost 0 . Although rates of succession and change in species composition probably differ between the Copper River Delta and the Tanana River floodplain, the mechanisms and patterns appear to be similar.

The northern portion of the uplifted marsh represents moose winter range, particularly the large contiguous expanse of willow-sweetgale and closed alder-willow used during less severe winters (Table 7). A minimal loss of open alder-willow in uplifted marsh is primarily because of succession to closed alder-willow and beyond. However, increases in closed alderwillow, willow-graminoid and willow-sweetgale communities represent substantial increases in available browse on transitional and summer ranges used by moose. Although only a portion of the west Copper River Delta uplifted marsh was mapped during this project, the processes and changes likely are representative of the entire uplifted marsh. Many areas of the coastal fringe of the Copper River Delta shifted from nonwoody herbaceous communities to types with abundant woody browse; however, tall forage species such as Sitka willow primarily are limited to the gravelly soils found in outwash plain. Mautz (1978) acknowledged that because adequate energy reserves play an important role in whether an animal survives winter, high-quality summer habitats are as 
important as winter range for temperate climate ungulates. Optimal summer range greatly improves the condition of animals entering winter (Stephenson 1995). However, given that the area of primary winter range on the Copper River Delta is small relative to the proportion of the Copper River Delta that is summer range (MacCracken et al. 1997), further increases in summer forage are unlikely to incur an increase in moose condition or numbers. Winter range availability, especially during periodic severe winters, will ultimately dictate the upper limit of the Copper River Delta moose population.

In addition to the changes in cover type in the uplifted marsh, the pattern of landscape heterogeneity changed between 1959 and 1986 (Table 3). The higher shape index (Patton 1975) during 1986 indicates greater interspersion of cover types. Figure 3 illustrates the beneficial juxtaposition of closed alderwillow and willow-sweetgale on moose summer range. The closed alder-willow cover type provides important thermal and hiding cover during calving season (MacCracken et al. 1997). The increased interspersion with willow-sweetgale, an important foraging habitat (MacCracken et al. 1997), may provide optimal summer habitat. Alternatively, the increase in edge may support higher densities of predators (Stephenson and Van Ballenberghe 1995a), which may partially confound the beneficial aspects of this improved interspersion. The increase in landscape heterogeneity and shrub invasion has had a negative impact on other species on the Copper River Delta such as dusky Canada geese (Branta canadensis occidentalis) (Thilenius 1990b; Stephenson and Van Ballenberghe 1995b).

The structural diversity across shrub communities of varying species composition results in heterogeneity of the forage base. On the Copper River Delta, the plant diversity resulting from such heterogeneity optimizes proximity and availability of forage when snow is absent and dense, but short willow communities such as willow-sweetgale are important (MacCracken et al. 1997). In contrast, taller communities such as open and closed alder-willow and the cottonwood communities become especially valuable during periods of deep snow. Spatial heterogeneity ensures the availability of optimal habitats within the framework of the dynamic climate on the Copper River Delta.

\section{Moose Carrying Capacity and Management}

Our estimates of nutritional carrying capacity during severe winters fell below those calculated by MacCracken et al. (1997) during the same period for moose on the Copper River Delta. This primarily occurred because we reduced available browse by compensating for browse burial under snow and by limiting the proportion of the diet that could be composed of lesspreferred forage species. Forage species that compose the diet of ungulates are the habitat characteristic that ultimately limits populations (Cook et al. 2004). Realistic estimates of carrying capacity should not assume that moose can consume $100 \%$ of the biomass of all forage species that occur in the diet. For example, Crete (1989) likely overestimated carrying capacity for moose in Quebec by not constraining his estimates to ensure adequate mixing, minimum nutrient concentrations, and limits on secondary compounds in the diet. We caution against developing estimates of carrying capacity irrespective of the forage base (Mercer and McLaren 2002) because of changes associated with vegetation succession or management. Our estimates of carrying capacity under milder conditions with no browse burial may not be directly compared to the estimates of MacCracken et al. (1997) because we only modeled the outwash plain. During mild winters, moose on the Copper River Delta use a portion of the uplifted marsh as well and this is reflected in MacCracken's estimates for mild winters. Furthermore, vegetation succession in the uplifted marsh is creating additional shrub habitat that provides more foraging habitat for moose during very mild winters.

Vast landscapes, such as the Copper River Delta, may appear to provide almost unlimited browse for moose; however, temporal and spatial constraints of weather and forage species distribution are expected to drastically reduce long-term carrying capacity. Turner et al. (1997) emphasized that resource availability within landscapes is not fixed. Reasonable expectations for moose population persistence or growth require understanding the spatial and temporal dynamics of vegetation communities on the Copper River Delta. Alaska's maritime climate, with its high precipitation, presents the potential for heavy snowfall to accompany slight declines in average winter temperatures. Winter habitats that ensure forage availability are declining. Hence, the pattern of vegetation succession on winter range coupled with periodic severe winters suggests a moose population that will become increasingly constrained on the Copper River Delta during severe winters. Potential methods exist and an understanding of the impressive magnitude of the response is known for habitat manipulation on the Copper River Delta (Stephenson et al. 1998b). In contrast to the opportunities for creating early successional habitat that exist in the northeastern United States through timber harvest (Koitzsch 2002), options on the Copper River Delta are likely to be more successful during earlier stages of vegetation succession. A decision regarding the need for habitat enhancement on the Copper River Delta also should be based on the population response to severe winters (e.g., adult vs. calf mortality), the periodicity of severe winters, the role of "topdown" versus "bottom-up" forces in limiting populations (Testa 2004a, 2004b), and the rate of recovery following population declines.

\section{MANAGEMENT IMPLICATIONS}

Resource users, especially consumptive ones, often demand that managers use historic benchmarks such as population highs in developing ungulate management goals, especially under the directive of intensive management in Alaska (Hundertmark and Schwartz 1996). Basing management upon such goals generally incorporates no knowledge of carrying capacity or vegetation change over time, and in many cases population highs may have been beyond carrying capacity and unsustainable. Advances in GIS resources, coupled with adequate vegetation sampling, make possible quantification of forage biomass over vast landscapes. When historic remotely sensed images are available, change detection analysis allows for quantifying vegetation succession. Carrying capacity estimates that incorporate vegetation succession provide managers with information that may be used to direct habitat manipulation or population management in a temporal and spatial context. Furthermore, GIS 
resources allow managers to move beyond measures of population density based simply on density per unit of land area, a commonly used metric for assessing population status. Instead, we now have the ability to estimate density per unit of habitat. Density estimates generated in the context of highquality habitat are far more meaningful for understanding carrying capacity. For example, the moose population on the Copper River Delta during our study was 299 animals (Nowlin 1995); a density estimate calculated for the entire study area of $830 \mathrm{~km}^{2}$ is 0.36 moose $\cdot \mathrm{km}^{-2}$; a relatively high density for Alaskan moose populations (Van Ballenberghe and Ballard 1997). More meaningfully, density calculated using only the 50 $\mathrm{km}^{2}$ of primary winter range used during severe winters is 6 moose $\cdot \mathrm{km}^{-2}$ and represents the potential for intraspecific competition for forage during winter. At current population levels, the carrying capacity estimate predicted in Table 8 indicates that during harsh winters, the moose population will exceed carrying capacity in the next decade. Understanding the ramifications of this requires continued monitoring of the nutritional condition of animals entering winter (Stephenson et al. 1998a) and estimating their reliance on winter forage resources necessary to survive winter. In addition to understanding the adequacy of the forage base relative to moose nutrition, impacts to native plant communities may need to be considered as well, as the relative density of herbivores increases.

\section{ACKNOWLEDGMENTS}

We thank S. O. Glasen and A. W. Stephenson for field assistance. S. Ranney and G. Ranney provided excellent fixed-wing aircraft support. K. Winterberger, R. Koleser, D. Lyon, R. Adams, D. Gettinger, and H. Johnson assisted with creation of map coverages.

\section{LITERATURE CITED}

Ballard, W. B., J. S. Whitman, and D. J. Reed. 1991. Population dynamics of moose in south-central Alaska. Wildlife Monograph 114:1-49.

Bo, S., AND 0. HJELJORD. 1991. Do continental moose ranges improve during cloudy summers? Canadian Journal of Zoology 69:1875-1879.

BoGGs, K. 1994. Hierarchical classification of community types, successional sequences, and landtype associations of the Copper River Delta. Anchorage, AK: Report to US Department of Agriculture, Chugach National Forest. 177 p.

BoGGs, K. 2000. Classification of community types, succesional sequences, and landscapes of the Copper River Delta, Alaska. Portland, OR: US Department of Agriculture, Forest Service, Pacific Northwest Research Station. General Technical Report PNW-GTR-469. 244 p.

Bryant, J. P. 1985. Feltleaf willow-snowshoe hare interactions: plant carbon/ nutrient balance and floodplain succession. Ecology 68:1319-1327.

Bryant, J. P., F. D. Provenza, J. Pastor, P. B. Reichardt, T. P. Clausen, and J. T. du TolT. 1991. Interactions between woody plants and browsing mammals mediated by secondary metabolites. Annual Review of Ecology and Systematics 22:431-446.

BuRRows, C. J. 1990. Processes of vegetation change. Boston, MA: Unwin Hyman. $551 \mathrm{p}$.

CaRY, J. R. 1985. Program DC80. Madison, WI: Department of Wildlife Ecology, University of Wisconsin. $7 p$.

Chapin, F. S., III, L. R. Walker, C. L. Fastie, and L. C. Sharman. 1994. Mechanisms of primary succession following deglaciation at Glacier Bay, Alaska. Ecological Monographs 64:149-175.

CoAdy, J. W. 1974. Influence of snow on behavior of moose. Naturaliste Canadien 101:417-436.
Connell, J. H., and R. O. Slatyer. 1977. Mechanisms of succession in natural communities and their role in community stability and organization. American Naturalist 111:1119-1144.

Cook, J. G., B. K. Johnson, R. C. Cook, R. A. Riggs, T. Delcurto, L. D. Bryant, and L. L. IRWIN. 2004. Effects of summer-autumn nutrition and parturition date on reproduction and survival of elk. Wildlife Monographs 155:1-61.

CRETE, M. 1989. Approximation of $\mathrm{K}$ carrying capacity for moose in eastern Quebec. Canadian Journal of Zoology 67:373-380.

Crow, J. H. 1968. Plant ecology of the Copper River Delta, Alaska [dissertation]. Pullman, WA: Washington State University. 120 p.

Dixon, K. R., and J. A. Chapman. 1980. Harmonic mean measure of animal activity areas. Ecology 61:1040-1044.

Haukioja, E., and K. Lehtlla. 1992. Moose and birch: how to live on low-quality diets. Trends in Ecology and Evolution 7:19-22.

Hobbs, N. T., and R. A. Spowart. 1984. Effects of prescribed fire on nutrition of mountain sheep and mule deer during winter and spring. Journal of Wildlife Management 48:551-560.

HobBs, N. T., And D. M. Swift. 1985. Estimates of habitat carrying capacity incorporating explicit nutritional constraints. Journal of Wildlife Management 49:814-822.

Hundertmark, K. J., W. L. Eberhardt, and R. E. Ball. 1990. Winter habitat use by moose in southeastern Alaska: implications for forest management. Alces 26:108-114.

Hundertmark, K. J., and C. C. Schwartz. 1996. Considerations for intensive management of moose in Alaska. Alces 32:15-24.

Jenkins, K. J., And R. G. WRight. 1987. Simulating succession of riparian spruce forests and white-tailed deer carrying capacity in northwestern Montana. Western Journal of Applied Forestry 2:80-83.

JoHnson, D. H. 1980. The comparison of usage and availability measurements for evaluating resource preference. Ecology 61:65-71.

KoItzsch, K. B. 2002. Application of a moose habitat suitability index model to Vermont wildlife management units. Alces 38:89-108.

Krummel, J. R., R. H. Gardner, G. Sugihara, R. V. O’Neill, and P. R. Coleman. 1987. Landscape patterns in a disturbed environment. Oikos 48:321-324.

Leresche, R. E., R. H. Bishop, and J. W. Coady. 1974. Distribution and habitats of moose in Alaska. Naturaliste Canadien 101:143-178.

MacCracken, J. G. 1992. Ecology of moose on the Copper River Delta, Alaska [dissertation]. Moscow, ID: University of Idaho. $320 \mathrm{p}$.

MacCracken, J. G., and V. Van Ballenberghe. 1993. Comparison of rumen and fecal analysis to estimate moose diets. Northwest Science 64:256-261.

MacCracken, J. G., V. Van Ballenberghe, and J. M. Peek. 1997. Habitat relationships of moose on the Copper River Delta in coastal south-central Alaska. Wildlife Monograph 136:1-52.

Mautz, W. W. 1978. Sledding on a bushy hillside: the fat cycle in deer. Wildlife Society Bulletin 6:88-90.

Mercer, W. E., and B. E. McLaren. 2002. Evidence of carrying capacity effects in Newfoundland moose. Alces 38:123-141.

Miquelle, D. G., and P. A. Jordan. 1979. The importance of diversity in the diet of moose. Proceedings of the North American Moose Conference and Workshop 15:54-79.

Miquelle, D. G., J. M. Peek, and V. Van Ballenberghe. 1992. Sexual segregation in Alaskan moose. Wildlife Monograph 122:1-57.

MorRISon, M. L. 2001. A proposed research emphasis to overcome the limits of wildlife-habitat relationship studies. Journal of Wildlife Management 65: 613-623.

National Oceanic and Atmospheric Administration. 1993. Climatological data annual summaries, Alaska. Asheville, NC: National Climatic Data Center.

Nowlin, R. A. 1995. Unit 6 moose. In: M. V. Hicks [ed.]. Survey-inventory management report. Juneau, AK: Alaska Department of Fish and Game. Federal Aid in Wildlife Restoration. Study 1.0, Grants W-23-5, W-24-1. p 45-65.

Oldemeyer, J. L., And W. L. Regelin. 1987. Forest succession, habitat management, and moose on the Kenai National Wildlife Refuge. Swedish Wildlife Research Supplement 1:163-179.

Parker, K. L., C. T. Robbins, and T. A. Hanley. 1984. Energy expenditures for 
locomotion by mule deer and elk. Journal of Wildlife Management 48: 474-488.

Patton, D. R. 1975. A diversity index for quantifying habitat edge. Wildlife Society Bulletin 3:171-173.

Peek, J. M., D. L. Urich, and R. J. Mackie. 1976. Moose habitat selection and relationships to forest management in northeastern Minnesota. Wildlife Monograph 48:1-65.

Porter, W. F., AND K. E. Church. 1987. Effects of environmental pattern on habitat preference analysis. Journal of Wildlife Management 51:681-685.

Potyondy, J. P., M. P. Meyer, and A. C. Mace, JR. 1975. Hydrologic response of the Copper River Delta-Controller Bay area, Alaska, to land emergence and uplift. Minneapolis, MN: University of Minnesota, Department of Forest Resources. $81 \mathrm{p}$.

Regelin, W. L., C. C. Schwartz, and A. W. Franzmann. 1987. Effects of forest succession on nutritional dynamics of moose forage. Swedish Wildlife Research Supplement 1:247-263.

Reiners, W. A., I. A. Worley, and D. B. Lawrence. 1971. Plant diversity in a chronosequence at Glacier Bay, Alaska. Ecology 52:55-69.

ReYnoLds, J. 1976. Copper River Delta moose population identity study. Juneau, AK: Alaska Department of Fish and Game, P-R Project Report, W-17-6 and W17-7. $21 \mathrm{p}$.

Saether, B.-E., and R. Andersen. 1990. Resource limitation in a generalist herbivore, the moose Alces alces: ecological constraints on behavioural decisions. Canadian Journal of Zoology 68:993-999.

Sandegren, F., R. Bergstrom, and P. Y. Sweanor. 1985. Seasonal moose migration related to snow in Sweden. Alces 21:321-338.

StePHenson, T. R. 1995. Nutritional ecology of moose and vegetation succession on the Copper River Delta, Alaska [dissertation]. Moscow, ID: University of Idaho. $172 \mathrm{p}$.

Stephenson, T. R., K. J. Hundertmark, C. C. Schwartz, and V. Van Ballenberghe. 1998a. Predicting body fat and body mass in moose with ultrasonography. Canadian Journal of Zoology 76:717-722.

Stephenson, T. R., and V. Van Ballenberghe. 1995a. Defense of one twin calf against wolves, Canis lupus, by a female moose, Alces alces. Canadian Field-Naturalist 109:251-253.

Stephenson, T. R., and V. Van Ballenberghe. 1995b. Wolf, Canis lupus, predation on dusky Canada geese, Branta canadensis occidentalis. Canadian Field-Naturalist 109:253-255.

Stephenson, T. R., V. Van Ballenberghe, and J. M. Peek. 1998b. Response of moose forages to mechanical cutting on the Copper River Delta, Alaska. Alces34:479-494.
Swihart, R., and N. Slade. 1985. Testing for independence of observations in animal movements. Ecology 66:1176-1184.

TESTA, J. W. 2004a. Population dynamics and life history trade-offs of moose (Alces alces) in south-central Alaska. Ecology 85:1439-1452.

TESTA, J. W. 2004b. Interaction of top-down and bottom-up life history trade-offs in moose (Alces alces). Ecology 85:1453-1459.

THILENIUS, J. F. 1990a. Woody plant succession on earthquake-uplifted coastal wetlands of the Copper River Delta, Alaska. Forest Ecology and Management 33/34:439-462.

THILENIUS, J. F. 1990b. Plant succession on earthquake uplifted coastal wetlands, Copper River Delta, Alaska. Northwest Science 64:259-262.

Turner, M. G., S. M. Pearson, W. H. Romme, and L. L. Wallace. 1997. Landscape heterogeneity and ungulate dynamics: what spatial scales are important? In: J. A. Bissonette [ED.]. Wildlife and landscape ecology: Effects of pattern and scale. New York, NY: Springer-Verlag. p 331-348.

USHER, M. B. 1981. Modelling ecological succession, with particular reference to Markovian models. Vegetatio 46:11-18.

Van Ballenberghe, V., and W. B. Ballard. 1997. Population dynamics. In: A. W. Franzmann and C. C. Schwartz [EDS.]. Ecology and management of the North American moose. Washington, DC: Smithsonian Institution Press. p 223-245.

Van Hulst, R. 1979. On the dynamics of vegetation: Markov chains as models of succession. Vegetatio 40:3-14.

VIERECK, L. A. 1966. Plant succession and soil development on gravel outwash of the Muldrow Glacier, Alaska. Ecological Monograph 36:181-199.

Viereck, L. A., C. T. Dyrness, A. R. Batten, and K. J. Wenzlick. 1992. The Alaska vegetation classification. Portland, OR: US Department of Agriculture, Forest Service, Pacific Northwest Research Station. General Technical Report PNWGTR-286. 278 p.

WaLker, L. R., J. C. ZASADA, AND F. S. Chapin, III. 1986. The role of life history processes in primary succession on an Alaskan floodplain. Ecology 67:1243-1253.

Warner, W. S., and W. W. Carson. 1991. Development of a monoscopic measurement system for small-format oblique photography. Small Camera Symposium; May 1991; London, UK. London, UK: Photogrammetric Society. $16 \mathrm{p}$.

WolfF, J. O., AND J. C. ZASADA. 1979. Moose habitat and forest succession on the Tanana River floodplain and Yukon-Tanana upland. Proceedings of the North American Moose Conference and Workshop 15:213-244. 